DOI: http://dx.doi.org/10.1590/S0104-64972015002317

\title{
Temporal variation in population structure of the isopod Urobopyrus processae Richardson, 1904 (Isopoda: Bopyridae) infesting the branchial chamber of the night shrimp Ambidexter symmetricus Manning and Chace, 1971 (Decapoda: Processidae)
}

Jennifer A. Rasch and Raymond T. Bauer

Department of Biology, University of Louisiana at Lafayette, Lafayette, 70504, USA. E-mail: jennrasch@ gmail.com

\begin{abstract}
Caridean shrimps are often infested by ectoparasites from the isopod family Bopyridae. Urobopyrus processae is a widespread species of bopyrid parasitizing the branchial (gill) chambers of members of the caridean family Processidae, including Ambidexter symmetricus. We examined hypotheses on differential infestation based on gender, castration of the host by the parasite, correlation between host and parasite size, and the fecundity of female parasites. Infestation rates varied from 1.3 to $32.1 \%$ between 2010 and 2011. Infested shrimps ranged from $1.26 \mathrm{~mm}$ to $6.24 \mathrm{~mm}$ carapace length (CL) between 2010 and 2011. Female shrimps were infested at a higher rate than males $(2010 \mathrm{P}$ $=0.0376 ; 2011 \mathrm{P}=0.0023)$. We report for the first time the differential selection between left and right branchial chambers in a caridean shrimp by a bopyrid parasite $(P=0.0209)$. Female parasite total length (TL) increased with host size (CL) in both years of sampling $\left(2010 \mathrm{R}^{2}{ }_{\text {adj }}=0.6863 ; 2011 \mathrm{R}^{2}\right.$ adj $\left.=0.8206\right)$. The size of male parasite TL was explained by both host CL $\left(2010 \mathrm{R}^{2}{ }_{\text {adj }}=0.4591 ; 2011 \mathrm{R}^{2}{ }_{\text {adj }}=0.5490\right)$ and parasite female TL $\left(2010 \mathrm{R}_{\text {adj }}^{2}\right.$ $=0.5606 ; 2011 \mathrm{R}^{2}$ adj $\left.=0.6195\right)$. The number of embryos in a brood of the female parasite (85-3096) was varied positively with female TL $\left(\mathrm{R}_{\text {adj }}^{2}=0.625\right)$. Our results show that the bopyrid-shrimp host relationship in processids is typical of those studied in other carideans, indicating similar selective pressures act on bopyrids infesting the branchial chambers of shrimps.
\end{abstract}

Key words: Parasitic castration, Parasitism, Reproduction, St. Joseph Bay.

\section{INTRODUCTION}

Decapod crustaceans are often infested by isopod parasites from the family Bopyridae. The majority of the members of this family are ectoparasites attaching within the branchial (gill) chamber or on the abdomens of their hosts (O'Brien and Van Wyk, 1985; Markham, 1986). These parasites do not kill their hosts as a requirement for development but instead depend on them for nutrition and as their habitat (Anderson and May, 1978). Most species are also usually parasitic castrators (Baudoin, 1975; Beck, 1979; O’Brien and Van Wyk, 1985; Romero-Rodríguez and Román-Contreras, 2013), although this is not always the case (Calado et al., 2006). It has been shown that in some cases the host may recover its reproductive ability if it outlives the parasite (Kuris, 1974; Oliveira and Masunari, 1998). Thus, bopyrid parasites play an important part in the population biology and regulation of their definitive host species (Kuris, 1974; Beck, 1979; Jay, 1989). The relationships between populations of hosts and their parasites may follow classical predator-prey interactions (Anderson and May, 1978; Romero-Rodríguez and Román-Contreras, 2013) and cause sex ratio distortion in their hosts (Hatcher et al., 1999).

When bopyrids castrate their hosts, two changes in host biology tend to occur: female ovaries do not mature, and males become feminized (Baudoin, 1975; Beck, 1980c; O’Brien 
and Van Wyk, 1985; Ayub and Ahmed, 2004). Bopyrid parasites often infest young shrimps and grow with the hosts in marine and brackish ecosystems (Pike, 1960; Kuris, 1974; Owens, 1983; Cash and Bauer, 1993; Roccatagliata and Lovrich, 1999; Romero-Rodríguez and RománContreras, 2013). However, in rare cases, parasites may infest older and larger host shrimps, e.g., in amphidromous shrimps which may be infested during reproductive migrations to estuaries (Conner and Bauer, 2010). Another possible side effect of a parasite on a host is gigantism. Not only do parasites often castrate their hosts, but they can also cause the host to grow larger than they would without the parasite (Baudoin, 1975). This process has been documented in the snail host Lymnaea Lamark, 1799 infested with the trematode parasite Echinostoma revolutum (Fröhlich, 1802) (Sorensen and Minchella, 1998), as well as in the water flea host Daphnia Müller, 1785 infected with the bacterial parasite Pasteuria ramosa Metchnikoff, 1888 (Ebert et al., 2004).

Bopyrid parasites also exhibit various patterns of infestation within decapod hosts. For example, the host sex with the larger body size tends to have a higher infestation rate in host species with sexual dimorphism in body size (Beck, 1979; Jay, 1989; Jordá and Roccatagliata, 2002). When there is no difference in size between male and female hosts, parasites tend to infest sexes equally (Beck, 1979; Miranda and Mantelatto, 2010).

Urobopyrus processae Richardson, 1904 (Peracarida: Epicaridea: Bopyridae) is a parasitic isopod with a distribution including the Atlantic Ocean, Caribbean Sea, Gulf of Mexico, and Mediterranean Sea (Markham, 1986). This parasite infests members of the family Processidae, including Processa fimbriata Manning and Chace, 1971, the shrimp from which Richardson (1904) described the parasite; Processa canaliculata Leach, 1815 (Bourdon, 1968); Processa edulis edulis (Risso, 1816) (Bourdon, 1968); Processa acutirostris Nouvel and Holthuis, 1957 (Bourdon, 1968); Processa robusta Nouvel and Holthuis, 1957 (Bourdon, 1968); and Ambidexter symmetricus Manning and Chace, 1971 (Markham, 1985). Previous work by Bourdon (1968) suggested that European processids are infested at smaller size classes with the host and parasite growing together, and that infestation rates varied from May through November. Rasch and Bauer (in press) showed that infestation of $A$. symmetricus by $U$. processae causes gigantism in the host, which has been seen in other animal species infested by parasites (Ebert et al., 2004; Hall et al., 2007). A taxonomic re-examination of this parasite may be necessary given the wide distribution and the supposed breadth of infestation across members of the family Processidae.

In this study, we tested several hypotheses about parasite biology and its effects on the host: that infestation rate of this parasite varied through time in $A$. symmetricus; that infestation of $A$. symmetricus differs between the sexes; and that this parasite castrates its hosts (Kuris, 1974; O’Brien and Van Wyk, 1985; Ayub and Ahmed, 2004). We predicted that parasites infest their shrimp hosts when both species are young, thereafter growing together with time (Kuris, 1974; Baudoin, 1975; O'Brien and Van Wyk, 1985; Hall et al., 2007). We also describe parasite fecundity. This study is the first to examine the population biology of $U$. processae infesting any shrimp species. This study also allows further insight into how bopyrid parasites affect the growth and reproduction of caridean shrimps over their lifetimes.

\section{MATERIALS AND METHODS}

\section{Study Area and Sampling}

A sampling site was established in the northeastern Gulf of Mexico in Eagle Harbor of St. Joseph Bay, Florida within T.H. Stone Memorial St. Joseph Peninsula State Park (29463.94”N $\left.85^{\circ} 24^{\prime} 12.22^{\prime \prime W}\right)$. Processid shrimps were collected in May-August 2010 and in April-October 2011, weather and low-tide permitting. Sampling focused on areas primarily covered by the seagrass Thalassia testudinum Banks ex König, 1805. The depth sampled at this site ranged from 0.5 to $1.3 \mathrm{~m}$ and samples were taken at night using a pushnet with a mouth size of $45 \times 23 \mathrm{~cm}$, with a 1 mm mesh (Bauer, 1985). The pushnet was pushed over the bottom and through the seagrass for a haphazard distance, with material collected then sorted by hand using headlamps; this was repeated for up to three hours. Any processid shrimps were separated and maintained in a bucket of ambient seawater until later preservation in a solution of $10 \%$ seawater formalin (10\% formaldehyde, $90 \%$ ambient seawater) and later washed with tapwater before transfer to $70 \%$ ethanol for permanent 
storage. Species name, carapace length, gender, ovigerous condition, and embryonic condition and presence of parasite(s) were recorded. Species were identified using keys from Manning and Chace (1971) and Abele and Kim (1986).

\section{Measurements and Counts}

Body size in shrimps was measured as carapace length $(\mathrm{CL} \pm 0.01 \mathrm{~mm})$, defined as the distance from the posterior edge of the orbit to the posterior lateral edge of the carapace and measured with an ocular micrometer. We examined the second pleopods for the presence (male) or absence (female) of an appendix masculina, the secondary male sexual character used to determine sex in carideans shrimps (Bauer, 2004). If an individual had damaged second pleopods, they were not included in the study. The degree of ovarian and embryonic condition of female shrimps was measured as in Bauer (1986; 1989; 1991).

Shrimps were considered infested if an isopod bopyrid parasite was present within a branchial chamber (Fig. 1A). If one side of the carapace was deformed (bulged outward) but empty, it was assumed that the shrimp had been infested recently, and these shrimps were still used in analysis of overall infestation rate, gender of infested shrimps, and side of infestation (Jay, 1989); Oliveira and Masunari, 1998; Miranda and Mantelatto, 2010). Some bopyrids were encountered loose in samples, presumably due to dislodgement during sampling and preservation; these were not used in any analyses since they could not be definitively matched to a host shrimp. All branchial parasites of the host shrimps were identified, using Markham (1985), as Urobopyrus processae (Fig. 1B-E). The total length ( $\mathrm{TL} \pm 0.01 \mathrm{~mm}$ ) of parasites found within branchial chambers was measured using a stereomicroscope with ocular micrometer, from the anterior edge of the cephalon to the posterior edge of the pleotelson in males (Fig. 1E) and in juvenile females (Fig. 1C), both of which are symmetrical in shape. However, female parasites are asymmetrical in shape (Fig. 1B, D) and were measured along the longest line from the anterior end to the end of the pleotelson (Cash and Bauer, 1993; Conner and Bauer, 2010). Development of embryos within the marsupium was divided into four successive stages: stage I, which is spherical in shape, whitish; stage II, which is oblong in shape and yellowish; stage III, which is oblong in shape and yellowish in color with brown pigments; and epicaridium larva, with external appendages and visible eyespots (Beck, 1980a; Romero-Rodríguez and Román-Contreras, 2013).

\section{Data Analysis}

A goodness of fit chi-square test was used to determine if there was an infestation preference by the parasites for female or male host shrimps as well as for infestation of the host's left or right branchial chamber. A full-cross ANOVA was used to address the question or whether parasite size was affected by month of sampling and/or sex of parasite. We used a Tukey-Kramer posthoc to determine interactions between Least Square Means (SAS Institute Inc. 2013). A linear regression compared female parasite TL with CL of the host shrimp, as female parasite length may be constrained by host size. We also used a linear regression to compare male parasite TL with both female parasite TL as well as, for completeness, the host shrimp CL. We used an analysis of covariance to test the hypothesis of no difference between the slopes of the regressions, using year and parasite gender as covariates (SAS Institute Inc. 2013). If there was only one parasite in a branchial chamber, it was considered female for analysis even if it was still in the cryptoniscus stage, as the first parasite larva that infests the branchial chamber becomes female (Reinhard, 1949).

If a cryptoniscus was found in the branchial chamber with a female parasite, it was considered a male (Reinhard, 1949). If there was a cryptoniscus larva on opposite sides of the branchial chamber $(\mathrm{N}=3)$, these parasites were not included in any analysis as it could not be determined which was the first infester. In shrimps with three or more parasites, only paired individuals (male and female or cryptoniscus and female) were used in the various analyses $(\mathrm{N}=5)$.

The variation in brood size (number of embryos) with female parasite size (TL) was examined using linear regression (SAS Institute Inc., 2013). We also analyzed the variation of embryo size (volume) with developmental stage. The greater $\left(\mathrm{d}_{2}\right)$ and lesser $\left(d_{1}\right)$ diameters of 10 embryos chosen haphazardly from each brood were measured. The mean volume of embryos brooded by female parasites were calculated using the formula $\mathrm{v}=\left(\pi^{*}\left(\mathrm{~d}_{1}\right)^{2 *} \mathrm{~d}_{2}\right) / 6$ (Turner and Lawrence, 1979; Romero-Rodríguez and Román-Contreras, 2013). 


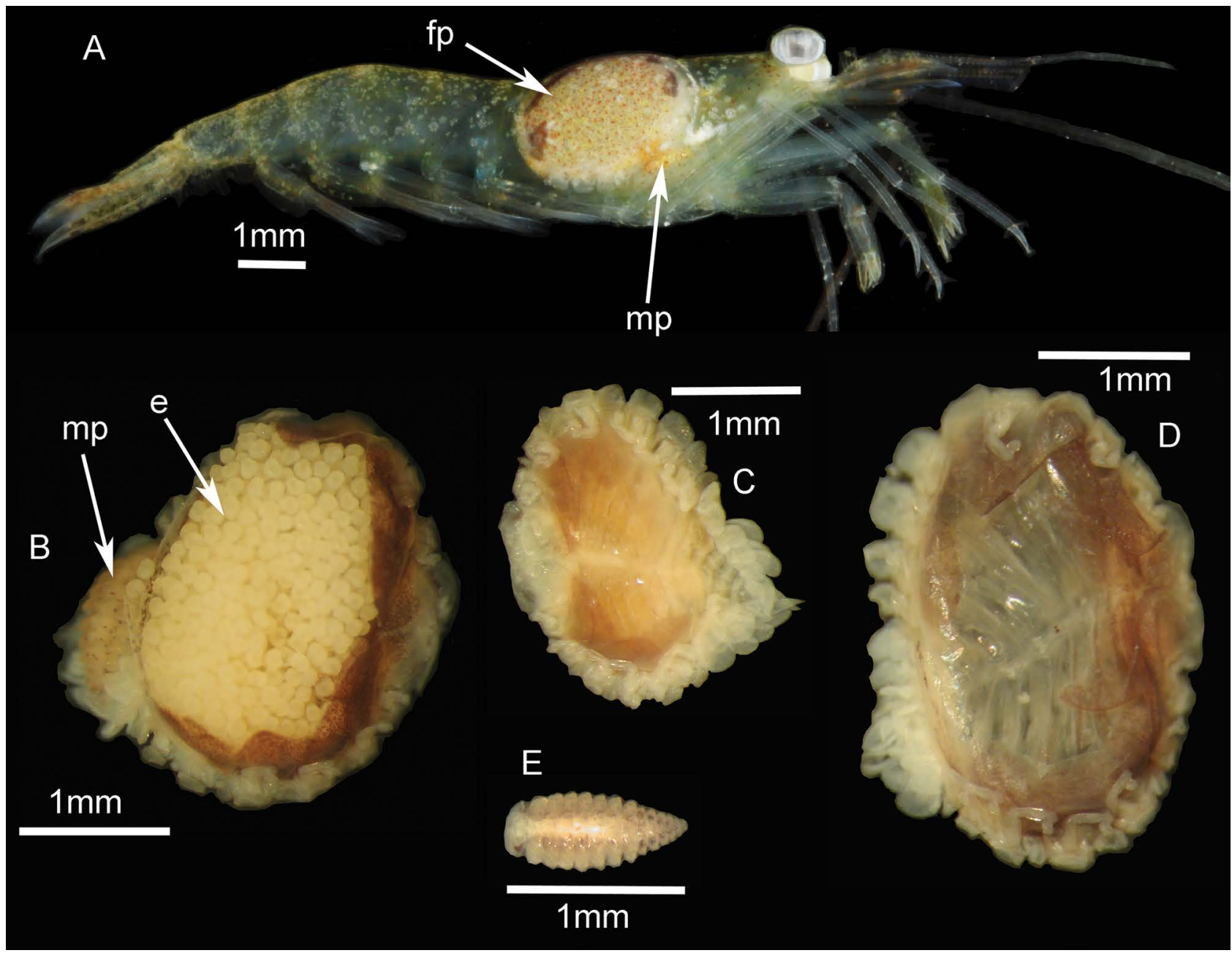

Figure 1. Urobopyrus processae. (A) U. processae female (fp, cephalic end) and male (mp) infesting a male shrimp Ambidexter symmetricus. (B) Female $U$. processae incubating embryos (e); (mp) male bopyrid. (C) Juvenile female U. processae (cephalon is to the left). (D) Adult female $U$. processae with empty marsupium (cephalon is to the right). (E) Adult male $U$. processae.

The size at sexual maturity of female parasites is an important reproductive parameter of populations. To estimate this parameter, we first plotted the relative proportion of female parasites in $0.3 \mathrm{~mm}$ size classes. The logistic function $\mathrm{y}=1 /$ $\left(1+\mathrm{e}^{-\mathrm{r}(\mathrm{TL}-\mathrm{TL} 50)}\right)$ was then fitted to the data, where $\mathrm{TL}_{50 \%}$ corresponds to the size at which $50 \%$ of the individuals are considered sexually mature and $r$ stands for the slope of the curve (King, 1995). We only included first infester parasites that had begun to show female differentiation for this analysis. We used maximum likelihood estimates for fitting (R Core Team, 2014). We used a Wilcoxon-Mann-Whitney test to determine if the distributions were different between years (SAS Institute Inc., 2013). We followed this test with a boot-strap analysis to test for differences in the shape of the distributions between 2010 and 2011. To do this we pooled data for all years and drew
1000 random samples. For each sample we drew 69 samples to represent 2010 and 53 samples to represent the 2011 data. In our analysis the shape of the distributions is summarized by the model parameters $r$ and $\mathrm{TL}_{50 \%}$. To perform this analysis we considered a modified version of the model:

$$
y=1 /\left(1+e^{-\left(r+\Delta r^{*} \text { year }\right)}\left(T L-\left(T L 50+\Delta T^{*} \text { year }\right)\right)\right.
$$

where year is coded as either 0 for 2010 or 1 for 2011. In our expanded model $\Delta \mathrm{r}$ gives the change in $r$ for the 2011 individuals relative to the 2010 individuals. Our expanded model also has $\Delta \mathrm{T}$ giving the change in $\mathrm{TL}_{50 \%}$ for the 2011 individuals relative to the 2010 individuals. For each of the 1000 replicates we recorded $\Delta \mathrm{r}$ and $\Delta \mathrm{T}$ to establish the distributions for these parameters under the null hypothesis of no differences between the 2010 and 2011 populations. We then compared the values for $\Delta \mathrm{r}$ and $\Delta \mathrm{T}$ computed from the observed data to the distributions. To 
compare the observed $\Delta \mathrm{r}$ to its distribution we found the number of replicates that had a value equal to or more extreme that the observed $\Delta r$ and divided this by the total number of replicates. This value can be interpreted as a p-value in this analysis. This process was repeated for $\Delta \mathrm{T}$. To determine if host CL of sexually mature female parasites was different between years, we used a two-sample t-test comparing host CL for 2010 and 2011 (SAS Institute Inc., 2013).

\section{RESULTS}

We collected a total of 1309 Ambidexter symmetricus in 2010 and 1177 in 2011, which was the only processid shrimp species collected infested with Urobopyrus processae. Monthly infestation rates in 2010 varied from $2.1 \%$ to $17.8 \%$ with a mean infestation rate of $8.6 \%$, while in 2011 infestation rates varied from $1.3 \%$ to $32.1 \%$ with a mean of $8.2 \%$, not including the July data ( $=2$, infestation rate $=50 \%$ ) because of its small sample size (Fig. 2). Shrimps ranged in size (CL) from $0.79 \mathrm{~mm}$ to $6.50 \mathrm{~mm}$. The size range of infested shrimps was from $1.56 \mathrm{~mm}$ to $6.24 \mathrm{~mm} \mathrm{CL}$ in 2010 , and $1.26 \mathrm{~mm}$ to $5.88 \mathrm{~mm} \mathrm{CL}$ in 2011 (Fig. 3). Parasite size (TL) ranged from $0.72 \mathrm{~mm}$ to $3.60 \mathrm{~mm}$ in 2010 , and $0.83 \mathrm{~mm}$ to $3.90 \mathrm{~mm}$ in 2011. Female parasite size (TL) was larger earlier in the year (April, May) but declined later in the year, while male parasites were consistent in TL across samples (Tabs. 1 and 2).

There were only 3 shrimps collected during the two years that had a cryptoniscus larva on both sides of the branchial chamber; these were not used in analyses. There were five shrimps collected with more than two parasites. All shrimps with three or four parasites were female, and collected between June 14th and June 17th in 2010 or 2011. No shrimp had more than four parasites in their branchial chamber. In these multiple infestations, only one female bopyrid was present, accompanied by a male, with the second infestation being either a cryptoniscus larva, a pair of cryptoniscus larvae, or in one case another male bopyrid (supernumerary male) all found in the opposite branchial chamber from the female-male pair.

Parasite infestation differed between male and female shrimps. In 2010, more female shrimps $(\mathrm{N}=67)$ were infested with $U$. processae than males $(\mathrm{N}=45)\left(\chi_{1}^{2}=4.32, \mathrm{P}=\right.$ $0.0376)$. In the 2011 samples, 64 females and 33 males were infested $\left(\chi^{2}{ }_{1}=9.28, \mathrm{P}=0.0023\right)$. Infestation also differed between right and left branchial chambers. In 2010 and 2011, there were 112 shrimps infested on the right branchial chamber, and 80 infested on the left branchial chamber $\left(\chi_{1}^{2}=5.33, \mathrm{P}=0.0209\right)$. Out of 131 parasitized female shrimps, only four were brooding embryos, including one which showed a developing ovary, indicating a possible future spawn. In all four cases, the parasites were cryptoniscus larvae, indicating a recent infestation.

The variation in female and male parasite TL was significantly explained by host CL in both 2010 and 2011 (Fig. 4). There was no combined effect of year* parasite gender*host CL on parasite TL, but there was an effect of parasite gender*host CL and an effect of host $\mathrm{CL}^{*}$ year on parasite TL (Fig. 4). However, the variation in male parasite TL was better explained by female parasite TL in both years (Fig. 5). There was no interaction between female $\mathrm{TL}^{*}$ year or effect of year on male TL (Fig. 5).

Brood size of the parasites ranged from 85 to 3096 embryos, and the volume of an embryo ranged from $0.00145-0.00238 \mathrm{~mm}^{3}$ depending on embryo stage (Tab. 3). Within a brood the size and developmental stage of the eggs did not vary. There was variation among broods between similarly sized female parasites when broken down into $0.5 \mathrm{~mm}$ size classes (Tab. 4); however there was a positive relationship present between number of parasite embryos brooded and female parasite TL (Fig. 6).

Female parasites differed in the size of sexual maturity between 2010 and 2011. The $\mathrm{TL}_{50 \%}$ was $1.09 \mathrm{~mm}$ in 2010 and $1.63 \mathrm{~mm}$ in 2011 (Fig. 7), and these differences were statistically significant. We found the value for $\Delta \mathrm{r}$ and $\Delta \mathrm{T}$ for the observed data were -0.937 and 0.565 , respectively. When we compared the observed value for $\Delta \mathrm{r}$ to its distribution we found that only a $1.8 \%$ of the replicates where equal to or more extreme that observing $\Delta r$ value. This value indicates that the observed $\Delta r$ was significantly different that zero at the $\mathrm{P}=0.018$ level. When we compared the observed value for $\Delta \mathrm{T}$ to its distribution we found that only a $<0.001 \%$ of the replicates where equal to or more extreme 


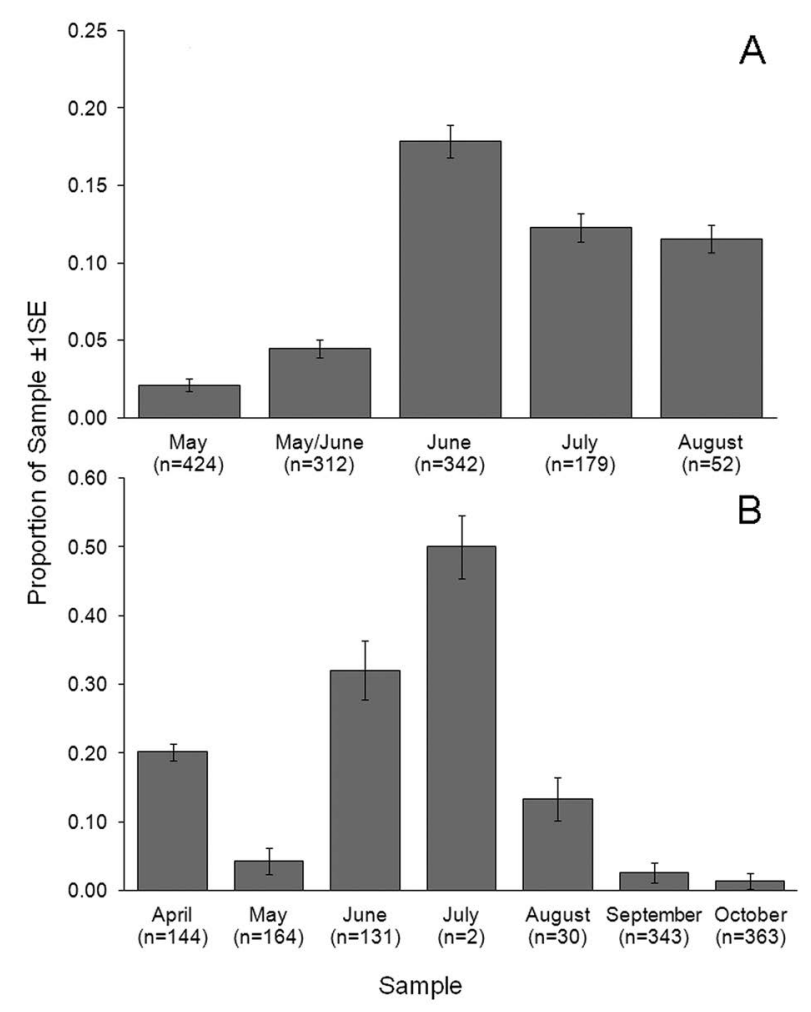

Figure 2. Urobopyrus processae. Proportion of shrimp Ambidexter symmetricus infested by U. processae in (A) 2010 and (B) 2011.

that observing $\Delta \mathrm{T}$ value. This value indicates that the observed $\Delta \mathrm{T}$ was significantly different that zero at the $\mathrm{P}<0.0001$ level. We found that the mean host length for shrimps $(\mathrm{CL} \pm \mathrm{SD}$ in $\mathrm{mm})$ infested by female parasites was $3.017 \mathrm{~mm} \pm 1.030$ in 2010 and $3.471 \mathrm{~mm} \pm 0.966$ in 2011 . There was a significant difference between these host CLs between years $(\mathrm{T}=-2.47, \mathrm{P}=0.0151, \mathrm{df}=119)$.

\section{Discussion}

Our results showed that the incidence of infestation by the bopyrid Urobopyrus processae of the processid shrimp Ambidexter symmetricus was higher than that found previously in other processid shrimps. Bourdon (1968) reported an overall infestation rate of $6.4 \%$ in Processa edulis edulis, ranging from a low of $5.3 \%$ in October/ November and a high of $8.9 \%$ in August; however more detailed data on monthly infestations were not provided. The percentage of $A$. symmetricus infested overall in both 2010 (8.6\%) and 2011 $(8.2 \%)$, ranging from a low of $1.4 \%$ in October of 2011 , to a high of $32.1 \%$ in June of 2011 . Bourdon (1968) did not report gender of hosts infested by $U$. processae for us to compare our data. However, a higher infestation rate of females is consistent with other bopyrid parasites known to infest sexually dimorphic carideans in which females are the larger sex (Romero-Rodríguez and Román-Contreras, 2013). Noël (1976) found a much lower incidence of infestation of processids by $U$. processae in his study, with only $-0.1 \%$ of P. edulis edulis infested overall, 4\% of Processa robusta Nouvel and Holthuis, 1957, and 2.8\% of Processa acutirostris. There is considerable variation in the infestation rates of $U$. processae within and across host processids, and the factors causing this variation should be a point of further study.

Bourdon (1968) found three individual shrimps which were infested with three or more parasites, similar to our study, and he suggested that Processa spp. may be unable to survive multiple infestations. However, it has been suggested that the first-established female parasite may inhibit the ability of other females to develop, this preventing bilateral infestations most of the time (Reinhard, 1949; Beck, 1979; Jay, 1989). Previous experiments also showed that when an immature female bopyrid is added to a host with an established adult female parasite, it later leaves (Reinhard, 1949). This would account for the small number of multiple infestations found in our study (five), and that multiple infestations never have more than one female bopyrid and usually involve cryptoniscus larvae. This is consistent with other studies reporting multiple infestations in caridean shrimps (Jay, 1989; Romero-Rodríguez and Román-Contreras, 2013). In our samples only one supernumerary male was present (in the opposite branchial chamber), and it was larger than the male paired with the female bopyrid as seen previously in Probopyrus pandalicola (Packard, 1879) infesting Palaemonetes paludosus (Gibbes, 1850) (Beck, 1980b).

Previous studies show branchial bopyrids generally occur equally in both the left and right gill chambers of their definitive hosts (Jay, 1989; Miranda and Mantelatto, 2010). Bourdon (1968) did report the percentage of left (48.4\%) and right side $(51.6 \%)$ infestations, but analysis was not conducted to determine if there was a statistical difference. Some bopyrids are known to show preferential branchial chamber side infestation in non-natantian decapod crustaceans. These differential infestations all have all been by members of the bopyrid subfamily Pseudioninae 


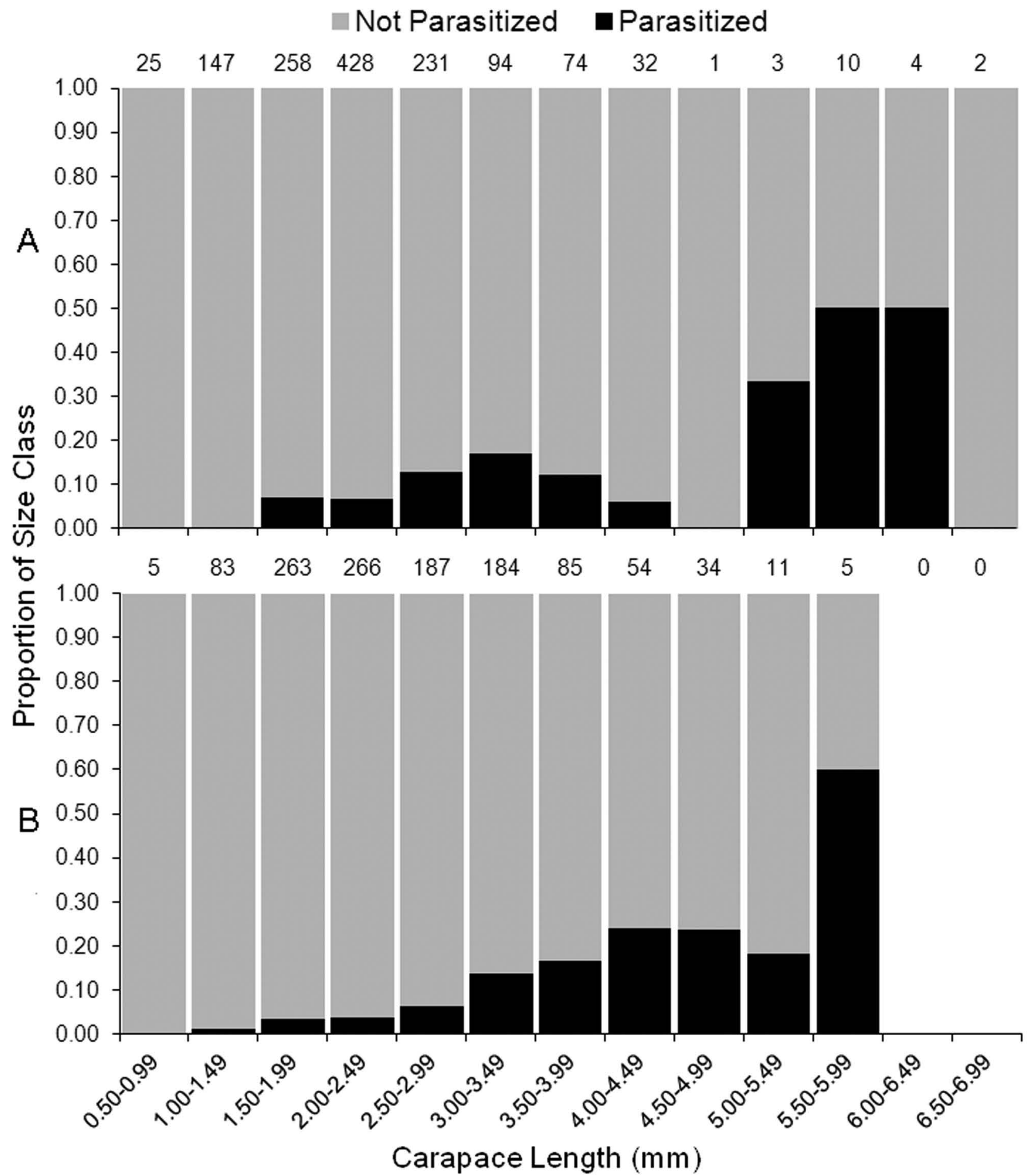

Figure 3. Urobopyrus processae. Proportion of each size class of shrimp Ambidexter symmetricus parasitized by U. processae in (A) 2010 and (B) 2011 (numbers above bars correspond to total number of individuals collected in that size class).

and the hosts are hermit crabs in Diogenidae and Paguridae (Markham, 1986) and in the false king crab Paralomis granulosa (Hombron \& Jacquinot, 1846) which is a member of Lithodidae (Roccatagliata and Lovrich, 1999). These three families belong to the infraorder
Anomura and all are characterized by some degree of body asymmetry. Processid shrimps show some asymmetry of thoracic appendages in the six currently described genera. In five genera, only the right first pereopod is chelate, and in some species, the left second pereopod (cheliped) is 
Table 1. Urobopyrus processae. Tukey-Kramer post hoc interactions of Least Square Means for effect of sample*sex on parasite total length (TL, in $\mathrm{mm}$ ) in 2010. F = female, $\mathrm{M}=$ male, $\mathrm{AG}=$ August, $\mathrm{JL}=\mathrm{July}, \mathrm{JN}=\mathrm{June}, \mathrm{MY}=\mathrm{May}, \mathrm{MJ}=$ end of May/beginning of June, $\mathrm{P}>0.05$ $=-, \mathrm{P}<0.05=^{*}, \mathrm{P}<0.01={ }^{* *}, \mathrm{P}<0.001={ }^{* * *}$.

\begin{tabular}{|c|c|c|c|c|c|c|c|c|c|c|}
\hline & $\mathrm{MY}^{*} \mathrm{~F}$ & $\mathrm{MY}^{*} \mathrm{M}$ & $\mathrm{MJ}{ }^{*} \mathrm{~F}$ & $\mathrm{MJ}^{*} \mathrm{M}$ & $\mathrm{JN}^{*} \mathrm{~F}$ & $\mathrm{JN}^{*} \mathrm{M}$ & $\mathrm{JL}^{*} \mathrm{~F}$ & $\mathrm{JL}^{*} \mathrm{M}$ & $\mathrm{AG}^{*} \mathrm{~F}$ & $\mathrm{AG}^{*} \mathrm{M}$ \\
\hline$M Y^{*} \mathrm{~F}$ & & $<0.0001$ & $<0.0001$ & $<0.0001$ & $<0.0001$ & $<0.0001$ & $<0.0001$ & $<0.0001$ & $<0.0001$ & $<0.0001$ \\
\hline $\mathrm{MY}^{*} \mathrm{M}$ & $* * *$ & & 0.8378 & 1.000 & 1.000 & 0.9856 & 0.8830 & 1.0000 & 0.9968 & 0.9992 \\
\hline$M J^{*} \mathrm{~F}$ & $* * *$ & - & & 0.9994 & 0.786 & 0.1194 & 0.9998 & 0.6422 & 0.9990 & 0.5650 \\
\hline$M J^{*} \mathrm{M}$ & $* * *$ & - & - & & 1.000 & 0.9994 & 1.0000 & 1.0000 & 1.0000 & 0.9997 \\
\hline $\mathrm{JN}^{*} \mathrm{~F}$ & $* * *$ & - & - & - & & 0.0933 & 0.5396 & 0.9990 & 0.9984 & 0.9785 \\
\hline $\mathrm{JN}^{*} \mathrm{M}$ & $* * *$ & - & - & - & - & & 0.0020 & 0.9887 & 0.5162 & 1.0000 \\
\hline $\mathrm{JL} * \mathrm{~F}$ & $* * *$ & - & - & - & - & $* *$ & & 0.5414 & 1.0000 & 0.6108 \\
\hline$J L^{*} \mathrm{M}$ & $* * *$ & - & - & - & - & - & - & & 0.9763 & 0.9980 \\
\hline $\mathrm{AG}^{*} \mathrm{~F}$ & $* * *$ & - & - & - & - & - & - & - & & 0.9097 \\
\hline $\mathrm{AG}^{*} \mathrm{M}$ & $* * *$ & - & - & - & - & - & - & - & - & \\
\hline
\end{tabular}

Table 2. Urobopyrus processae. Tukey-Kramer post hoc interactions of Least Square Means for effect of sample* gender on parasite total length $(\mathrm{TL}$, in $\mathrm{mm})$ in 2011. $\mathrm{F}=$ female, $\mathrm{M}=$ male, $\mathrm{AP}=$ April, $\mathrm{AG}=$ August, $\mathrm{JN}=$ June, MY = May, OC = October, $\mathrm{SP}=\mathrm{September}, \mathrm{P}>$ $0.05=-, \mathrm{P}<0.05=*, \mathrm{P}<0.01={ }^{* *}, \mathrm{P}<0.001={ }^{* * *}$.

\begin{tabular}{|c|c|c|c|c|c|c|c|c|c|c|c|c|c|}
\hline & $\mathrm{AP}^{*} \mathrm{~F}$ & $\mathrm{AP}^{*} \mathrm{M}$ & $M Y^{*} \mathrm{~F}$ & $\mathrm{MY}^{*} \mathrm{M}$ & $\mathrm{JN}^{*} \mathrm{~F}$ & $\mathrm{JN}^{*} \mathrm{M}$ & $\mathrm{JL}^{*} \mathrm{~F}$ & $\mathrm{AG}^{*} \mathrm{~F}$ & $\mathrm{AG}^{*} \mathrm{M}$ & $\mathrm{SP}^{*} \mathrm{~F}$ & $\mathrm{SP}^{*} \mathrm{M}$ & $\mathrm{OC}^{*} \mathrm{~F}$ & $\mathrm{OC}^{*} \mathrm{M}$ \\
\hline $\mathrm{AP}^{*} \mathrm{~F}$ & & $<0.0001$ & 0.9905 & 0.0013 & $<0.0001$ & $<0.0001$ & 0.1502 & 0.1291 & 0.0007 & $<0.0001$ & 0.0003 & 0.1784 & 0.0003 \\
\hline $\mathrm{AP}^{*} \mathrm{M}$ & $* * *$ & & 0.0868 & 1.0000 & 1.0000 & 0.9924 & 0.9999 & 0.9974 & 0.9986 & 1.0000 & 0.9913 & 0.9385 & 0.9999 \\
\hline $\mathrm{MY}^{*} \mathrm{~F}$ & - & - & & 0.2015 & 0.1359 & 0.0065 & 0.5742 & 0.9232 & 0.0912 & 0.0404 & 0.0551 & 0.9764 & 0.0924 \\
\hline $\mathrm{MY}^{*} \mathrm{M}$ & $* *$ & - & - & & 0.9998 & 1.0000 & 1.0000 & 0.9935 & 1.0000 & 1.0000 & 0.9999 & 0.9389 & 1.0000 \\
\hline $\mathrm{JN}^{*} \mathrm{~F}$ & $* * *$ & - & - & - & & 0.7649 & 0.9992 & 0.9999 & 0.9746 & 0.9927 & 0.9233 & 0.9885 & 0.9915 \\
\hline $\mathrm{JN}^{*} \mathrm{M}$ & $* * *$ & - & ** & - & - & & 1.0000 & 0.8045 & 1.0000 & 1.0000 & 1.0000 & 0.4297 & 1.0000 \\
\hline $\mathrm{JL}^{*} \mathrm{~F}$ & - & - & - & - & - & - & & 0.9909 & 1.0000 & 0.9652 & 1.0000 & 1.0000 & 1.0000 \\
\hline $\mathrm{AG}^{*} \mathrm{~F}$ & - & - & - & - & - & - & - & & 0.9161 & 0.9658 & 0.8397 & 1.0000 & 0.9554 \\
\hline $\mathrm{AG}^{*} \mathrm{M}$ & $* *$ & - & - & - & - & - & - & - & & 1.0000 & 1.0000 & 0.7331 & 1.000 \\
\hline $\mathrm{SP}^{*} \mathrm{~F}$ & $* * *$ & - & * & - & - & - & - & - & - & & 0.9999 & 0.7746 & 1.0000 \\
\hline $\mathrm{SP}^{*} \mathrm{M}$ & $* *$ & - & - & - & - & - & - & - & - & - & & 0.6048 & 1.0000 \\
\hline $\mathrm{OC}^{*} \mathrm{~F}$ & - & - & - & - & - & - & - & - & - & - & - & & 0.7994 \\
\hline $\mathrm{OC}^{*} \mathrm{M}$ & $* *$ & - & - & - & - & - & - & - & - & - & - & - & \\
\hline
\end{tabular}

longer than right (Manning and Chace, 1971; Hayashi, 1975). The possible differential selection of a branchial chamber by $U$. processae infesting A. symmetricus is the first such case in a caridean shrimp, and the first by a non-Pseudioninae bopyrid in any decapod (Urobopyrus Richardson, 1904 is in subfamily Bopyrinae).

Urobopyrus processae appears to castrate most female $A$. symmetricus that they infest. Of the 131 female shrimps with parasites, only 3 carried embryos, and only one showed ovarian development. Given the small size and early developmental stage of the parasites on these latter four shrimps, it is likely they were new infestations and did not have enough time yet to influence the reproductive capabilities of these host females. The ovary probably would have degenerated as the young parasite transitioned into a reproductive female (Baudoin, 1975; Beck, 1980c; Masunari et al., 2000). The castration of decapod hosts by bopyrids is a well known phenomenon (Baudoin, 1975; Beck, 1979; O’Brien and Van Wyk, 1985; Oliveira and Masunari, 1998; Masunari et al., 2000; Romero-Rodríguez and Román-Contreras, 2013). The most likely explanation is that the energy resources needed for host reproduction are taken up by the bopyrid female to produce its own broods of embryos. Additionally, the bopyrid may disrupt the host endocrine system affecting reproduction (Calado et al., 2005). Males of $A$. symmetricus and other carideans might also be castrated by bopyrids, but Calado et al. (2005) found that parasitized individuals of the shrimp Lysmata seticaudata (Risso, 1816) in the simultaneous hermaphrodite stage could mate and inseminate as males although they were unable to 


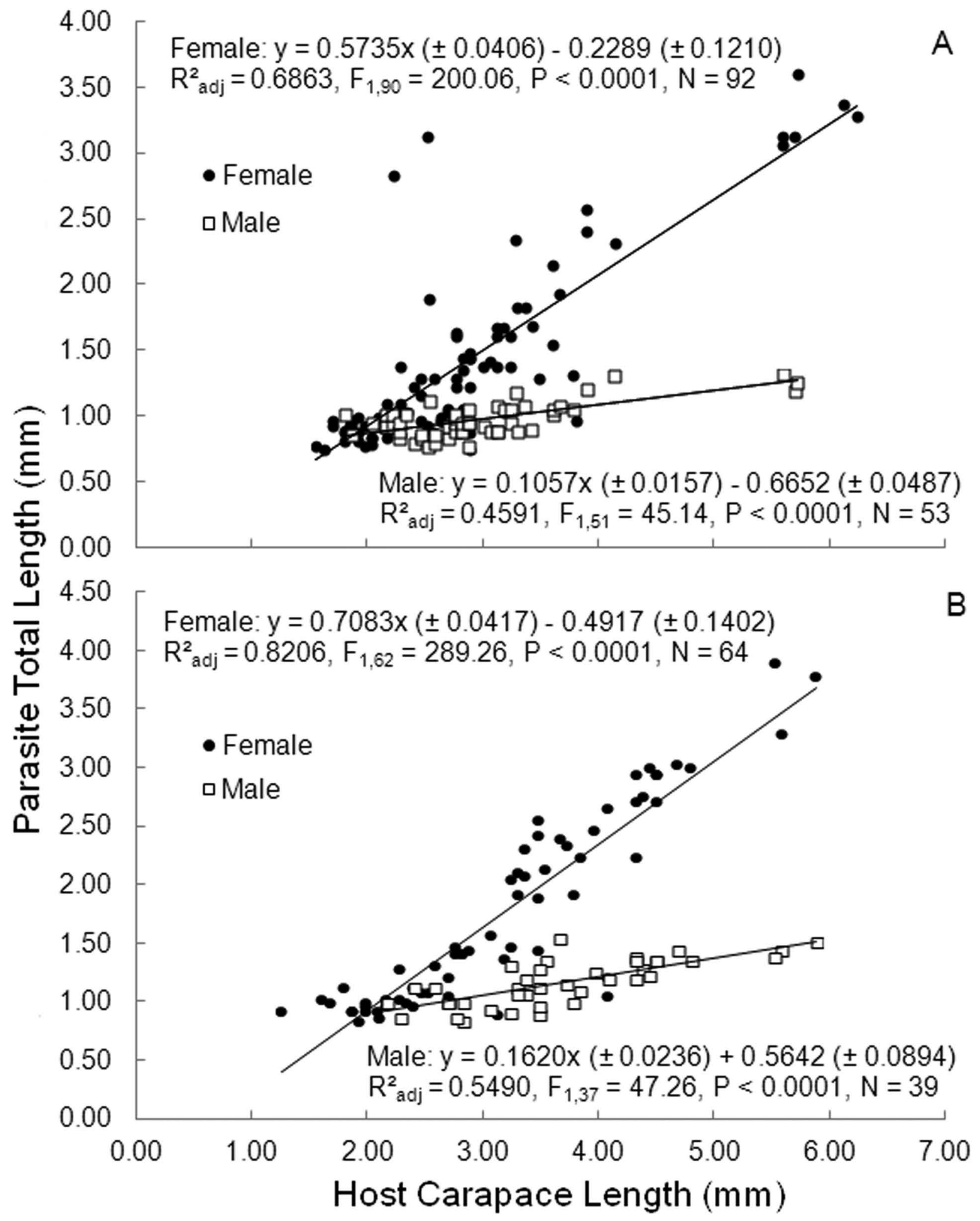

Figure 4. Urobopyrus processae. Variation of the total length (TL, in $\mathrm{mm}$ ) of female and male parasites as a function of host carapace length (CL, in mm) for (A) 2010 and (B) 2011. There was an effect of parasite gender*host CL $(\mathrm{P}<0.0001)$ and an effect of host $C L^{*}$ year $(\mathrm{P}=0.0093)$ on parasite TL.

produce embryos. Thus, the lower energetic needs of sperm production may allow males to mate and inseminate normally, a hypothesis which needs to be tested with bopyridized male carideans.
We found that female parasites are smaller in size as the year progresses, which is consistent with other data (Rasch and Bauer, in press) showing that the host shrimps are larger in size in 


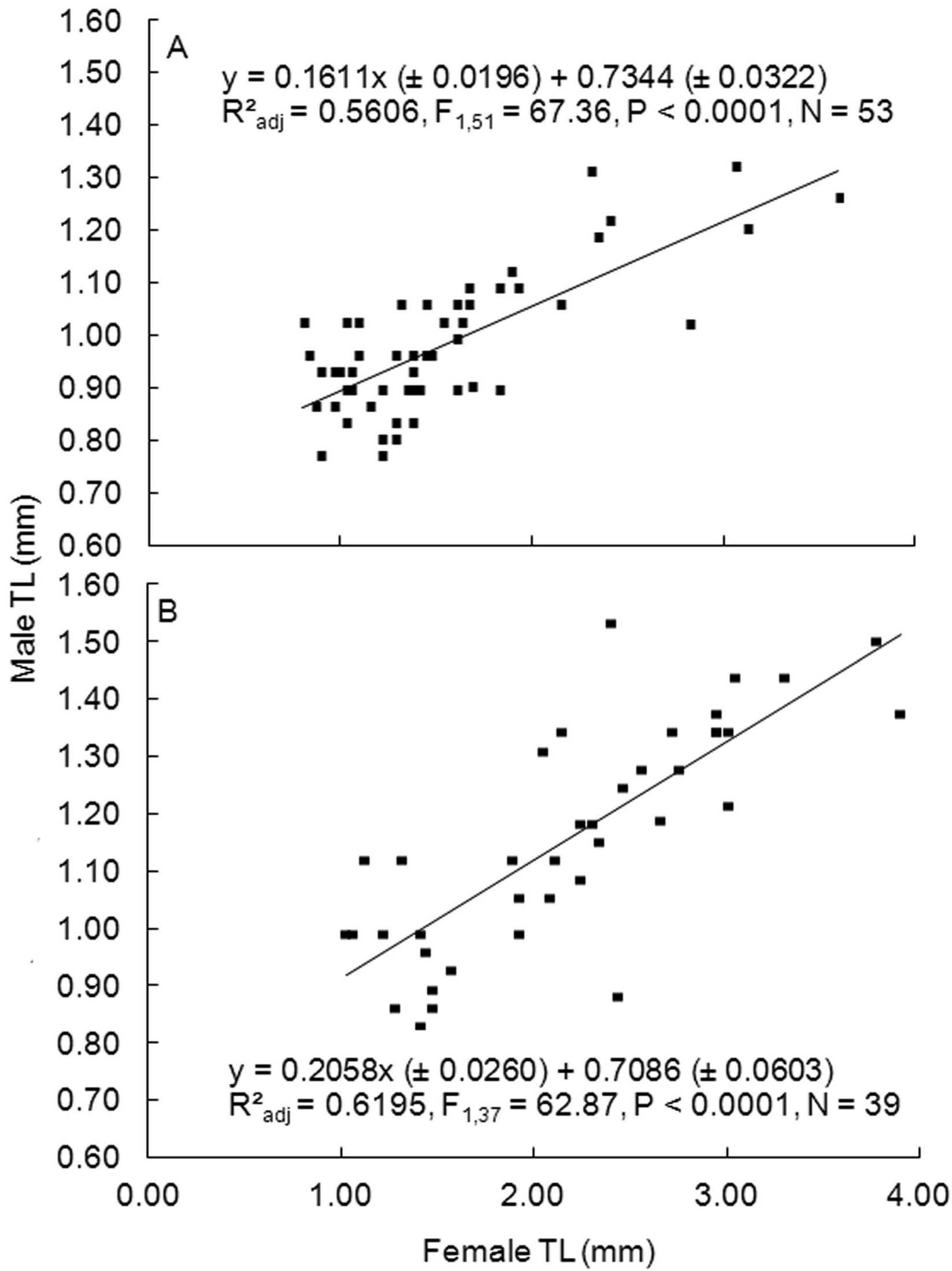

Figure 5. Urobopyrus processae. Variation in total length (TL, in $\mathrm{mm}$ ) of male parasites as explained by female parasite TL for (A) 2010 and (B) 2011. There was no interaction between female TL*year $(\mathrm{P}=0.1658)$ or effect of year on male TL $(\mathrm{P}=0.6857)$. 
Table 3. Urobopyrus processae. Fecundity and embryo, epicaridium volume of U. processae infesting shrimp Ambidexter symmetricus, based on developmental stage.

\begin{tabular}{lcccccc}
\hline Stage & $\mathrm{N}$ & $\overline{\mathrm{X}}$ Brood Size & $\overline{\mathrm{X}}$ Parasite Female TL $(\mathrm{mm})$ & $\mathrm{d}_{2}$ & $\mathrm{~d}_{1}$ & Volume $_{\left(\mathrm{mm}^{3}\right)}$ \\
\hline Stage I & 15 & $724 \pm 616$ & $2.46 \pm 0.47$ & 0.159 & 0.132 & 0.00145 \\
Stage II & 9 & $554 \pm 669$ & $2.52 \pm 0.44$ & 0.169 & 0.138 & 0.00169 \\
Stage III & 5 & $1043 \pm 1044$ & $3.00 \pm 0.63$ & 0.210 & 0.141 & 0.00219 \\
Epicaridium Larva & 4 & $1392 \pm 1500$ & $3.09 \pm 0.84$ & 0.222 & 0.143 & 0.00238 \\
All Stages & 33 & $807 \pm 835$ & $2.63 \pm 0.57$ & 0.177 & 0.136 & 0.00171 \\
\hline
\end{tabular}

Table 4. Urobopyrus processae. Mean brood size based on female parasite size class.

\begin{tabular}{lccc}
\hline Size Class $(\mathrm{mm})$ & $\mathrm{N}$ & Range of Brood Size & Mean Brood Size \pm SD \\
\hline $1.50-1.99$ & 4 & $154-291$ & $208 \pm 61$ \\
$2.00-2.49$ & 12 & $85-523$ & $317 \pm 204$ \\
$2.50-2.99$ & 8 & $161-2119$ & $890 \pm 593$ \\
$3.00-3.49$ & 6 & $89-2220$ & $1112 \pm 769$ \\
$3.50-3.99$ & 3 & $2208-3086$ & $2729 \pm 464$ \\
\hline
\end{tabular}

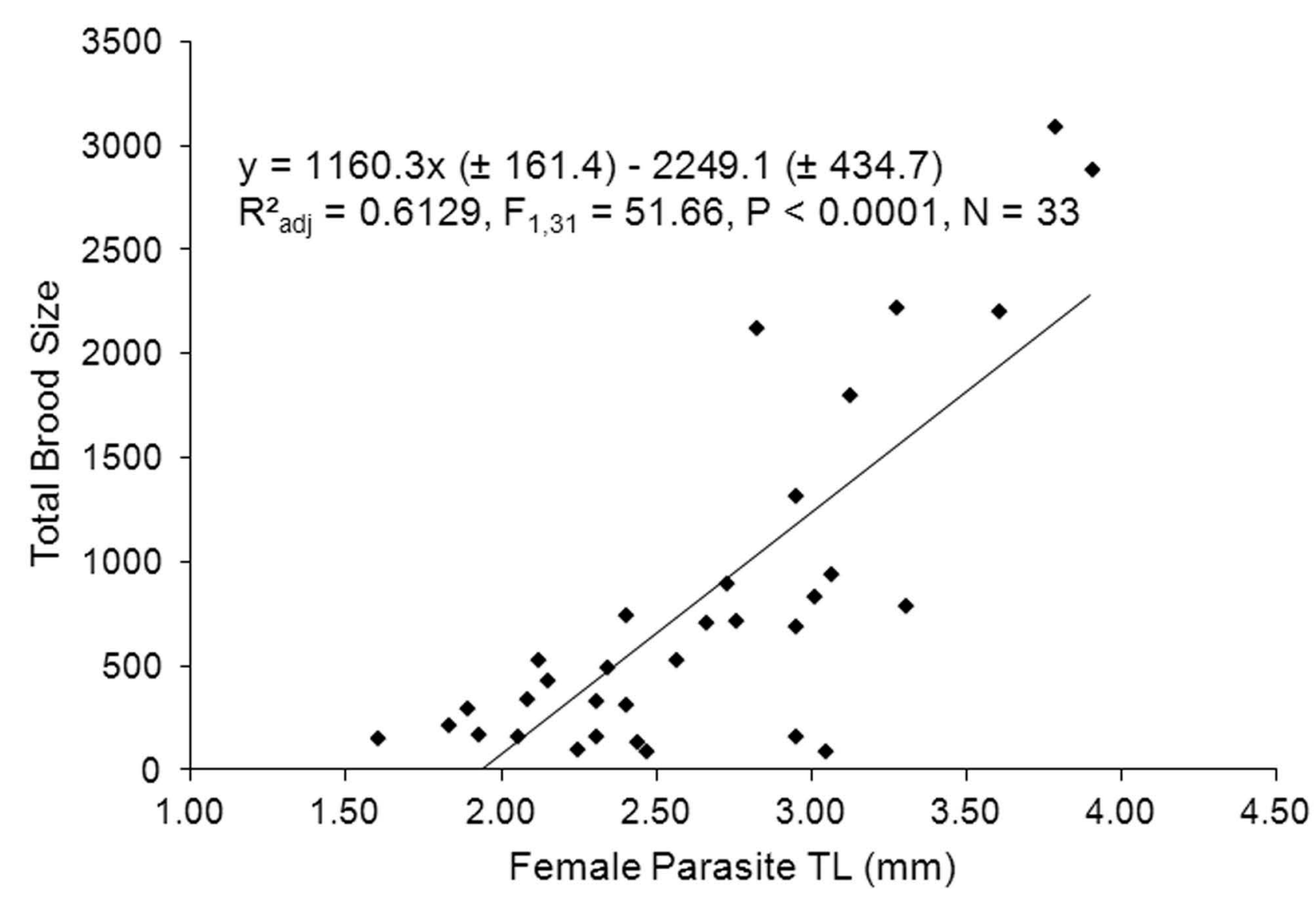

Figure 6. Urobopyrus processae. Variation in number of embryos in a brood as explained by female total length (TL, in mm).

the population sampled earlier in the year (April/ May), and smaller in size later in the summer (July, August, September). This change in the host population most likely is due to recruitment of shrimp postlarvae and death of larger older individuals during the summer. Female parasite TL increases with host size, and thus smaller newly recruited hosts as the summer progresses would result in smaller female parasites more recently infesting the younger, smaller shrimps. Male parasites appear to be limited in TL because they are constrained by the size of the female parasite, as males fit into a space on the female pleotelson. As noted, female parasite size is constrained by host size (the size of the branchial chamber, which the female fills). Positive correlation of female parasite 


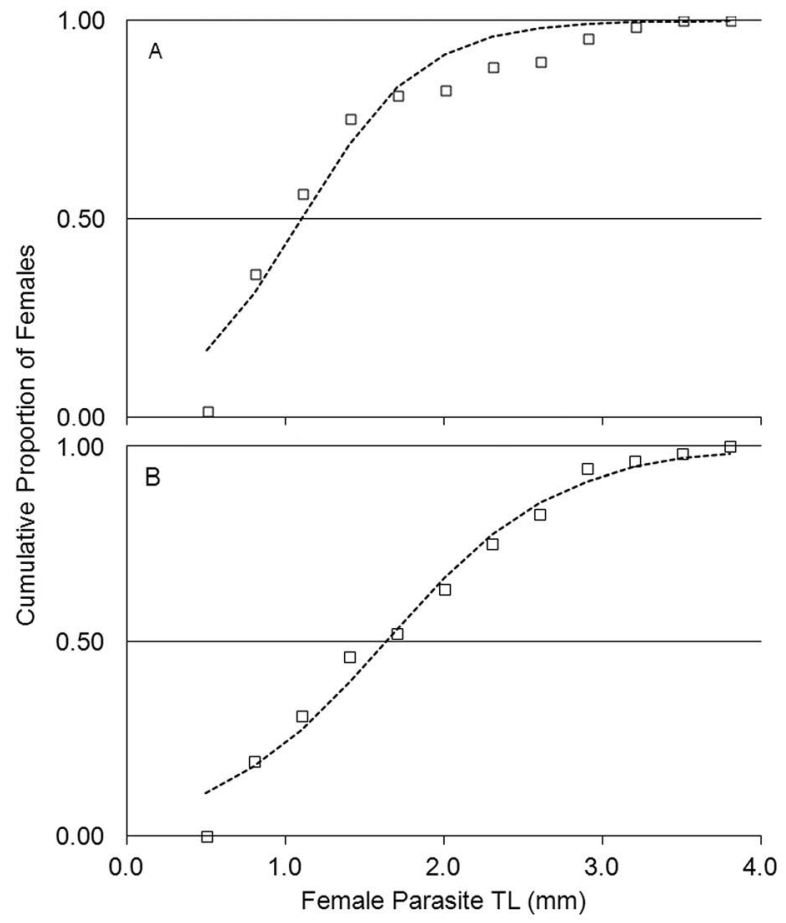

Figure 7. Urobopyrus processae. Size at sexual maturity based on the total length (TL, mm): $\mathrm{TL}_{50 \%}$ of females A: $2010(\mathrm{n}=69, \mathrm{r}$ $\left.=2.65, \mathrm{TL}_{50 \%}=1.09 \mathrm{~mm}\right) ; \mathrm{B}: 2011\left(\mathrm{n}=52, \mathrm{r}=1.84, \mathrm{TL}_{50 \%}=\right.$ $1.63 \mathrm{~mm})$.

TL is commonly reported in bopyrid parasite-host relationships, suggesting that the host is infested when very young, and the host and parasite then grow together (Roccatagliata and Lovrich, 1999; Romero-Rodríguez and Román-Contreras, 2013). Anderson (1990) showed experimentally that infestation of the shrimp Palaemonetes pugio Holthuis, 1949 by Probopyrus pandalicola occurs mainly in the shrimp's zoeal or young postlarval stages. Our data show that growth of the female bopyrid is strongly linked to host size; however some temporal variation also existed and needs to be further examined. Male parasites begin association with the female parasite soon after the latter becomes established in the host branchial chamber, consistent with male bopyrids of other species, and the two grow together to maturity (Beck, 1980a; Jay, 1989; Cash and Bauer, 1993).

The size of broods incubated by female $U$. processae is positively correlated with female parasite size (TL) (Beck, 1980a; RomeroRodríguez and Román-Contreras, 2008; 2013). Thus, larger hosts which suffer gigantism (Rasch and Bauer, in press) would have larger parasites within their branchial chambers, and these larger female parasites would be able to produce larger broods. The slight variation in brood size among similarly sized female parasites, but high variation among differently sized female parasites is consistent with observations in broods of other bopyrids parasitizing caridean shrimps, such as Probopyrus pandalicola infesting Palaemonetes paludosus (Beck, 1980b), Bopyrinella thorii (Richardson, 1904) on Thor floridanus Kingsley, 1878 (Romero-Rodríguez and Román-Contreras, 2008), Bopyrina abbreviata Richardson, 1904 on Hippolyte zostericola (Smith, 1873) (RomeroRodríguez and Román-Contreras, 2013), and Argeia pugettensis Dana, 1853 on Crangon francisorum francisorum Stimpson, 1856 (Jay, 1989).

The higher incidence of infestation reported here in female $A$. symmetricus is consistent with that reported in other bopyrid parasites infesting caridean shrimps where females are the larger host (Beck, 1979; Jay, 1989). This parasite adaptation enables parasite females to produce larger broods and maximize fecundity, as the female parasite is limited by host size, and brood size is also limited by host size as mentioned above (Beck, 1979; Jay, 1989; Miranda and Mantelatto, 2010). The range of brood size and embryo size seen in $U$. processae is consistent with the values reported for a variety of bopyrid parasites infesting caridean shrimps as reported by Romero-Rodríguez and RománContreras (2013).

The size at sexual maturity, $\mathrm{L}_{50 \%}$ (in this study parasite $\left.\mathrm{TL}_{50 \%}\right)$, is an important population parameter for comparing reproductive maturity within and across taxa (King, 1995) that may vary among and between populations (Pardo et al., 2009). The $\mathrm{TL}_{50 \%}$ for $U$. processae indicated that approximately $50 \%$ of female parasites reached sexual maturity between 1.10-1.63 mm TL, with a significant difference between years for both the slope and the y-intercept of the lines. This suggests that some abiotic or biotic factors may be influencing sexual development in this parasite from year to year and warrants further study. One factor may be host CL. Our data showed that shrimps with female parasites in 2011 were larger than those in 2010, and this could influence sexual maturity in the parasites.

Urobopyrus processae is known to occur in several Processa species (Bourdon, 1968; Markham, 1985; 1986), but only infested A. symmetricus we collected, and not any 
other member of the family Processidae that were taken in the same collections [Processa bermudensis (Rankin, 1900), Processa hemphilli Manning and Chace, 1971, Processa riveroi Manning and Chace, 1971]. This speciesspecific host infestation could suggest this parasite may be a different species, or subspecies. Very little is known about parasitic development during the infestation of the host, since most of the focus is on the fully developed adult parasite morphology (Anderson, 1990). Parasites and hosts coevolve with each other, so that understanding the biology of the parasite is critical to understanding the ecology of the host and vice versa. The relationship between $U$. processae and its host $A$. symmetricus warrants further investigation to determine if the patterns reported from our data are consistent among different locations and other processid host species.

\section{ACKNOWLEDGEMENTS}

We thank the Florida Fish and Wildlife Conservation Committee and the Florida Department of Environmental Protection for allowing us to collect samples in T.H. Stone Memorial St. Joseph Peninsula State Park, Florida. We would like to acknowledge support of the St. Joseph Bay Buffer Preserve and the Friends of St. Joseph's Bay for lodging. We thank S.M. Duke-Sylvester for statistical assistance and B.E. Felgenhauer for useful comments on this manuscript. We thank numerous graduate students from the University of Louisiana at Lafayette who participated in the field work, for which we would not have been able to do this research. Funding was provided by a Louisiana Board of Regents Fellowship and by the University of Louisiana at Lafayette Graduate Student Organization to the first author. This is Contribution No. 173 of the Laboratory for Crustacean Research.

\section{REFERENCES}

Abele, L.G. and Kim, W. 1986. An illustrated guide to the marine decapod crustaceans of Florida. State of Florida, Department of Environmental Regulation, 8, 1-760.

Anderson, G. 1990. Postinfection mortality of Palaemonetes spp. (Decapoda: Palaemonidae) following experimental exposure to the bopyrid isopod Probopyrus pandalicola (Packard) (Isopoda: Epicaridea). Journal of Crustacean Biology, 10(2): 284-292.
Anderson, R.M. and May, R.M. 1978. Regulation and stability of host-parasite population interactions I. Regulatory processes. Journal of Animal Ecology, 47(1): 219-247.

Ayub, Z. and Ahmed, M. 2004. Study on the host-parasite relationship of Parapenaeopsis stylifera (H. Milne Edwards) (Decapoda: Penaeidae) and Parapenaeon japonica (Thielemann) (Isopoda: Bopyridae). Hydrobiologia, 523(1-3): 225-228.

Baudoin, M. 1975. Host Castration as a Parasitic Strategy. Evolution, 29(2): 335-352.

Bauer, R.T. 1985. Penaeoid shrimp fauna from tropical seagrass meadows: Species composition, diurnal, and seasonal variation in abundance. Proceedings of the Biological Society of Washington, 98(1): 177-190.

Bauer, R.T. 1986. Sex change and life history pattern in the shrimp Thor manningi (Decapoda: Caridea): a novel case of partial protandric hermaphroditism. Biological Bulletin, 170(1): 11-31.

Bauer, R.T. 1989. Continuous reproduction and episodic recruitment in nine shrimp species inhabiting a tropical seagrass meadow. Journal of Experimental Marine Biology and Ecology, 127(2): 175-187.

Bauer, R.T. 1991. Analysis of embryo production in a caridean shrimp guild from a tropical seagrass meadow. p. 181-192. In: A. Wenner \& A. Kuris (eds), Crustacean Egg Production. Crustacean Issues, Vol. 7. Rotterdam, A.A. Balkema Press.

Bauer, R.T. 2004. Remarkable shrimps: Adaptations and natural history of the carideans. Animal Natural History Series, Vol. 7. Norman, University of Oklahoma Press, 282p.

Beck, J.T. 1979. Population interactions between a parasitic castrator, Probopyrus pandalicola (Isopoda: Bopyridae), and one of its freshwater shrimp hosts, Palaemonetes paludosus (Decapoda: Caridea). Parasitology, 79(3): 431449.

Beck, J.T. 1980a. Life history relationships between the bopyrid isopod Probopyrus pandalicola and one of its freshwater shrimp hosts Palaemonetes paludosus. American Midland Naturalist, 104(1): 135-154.

Beck, J.T. 1980b. Larval and adult habitats of a branchial bopyrid Probopyrus pandalicola on one of its freshwater shrimp hosts Palaemonetes paludosus. Crustaceana, 38(3): 265-270.

Beck, J.T. 1980c. The effects of an isopod castrator, Probopyrus pandalicola, on the sex characters of one of its caridean shrimp hosts, Palaemonetes paludosus. Biological Bulletin, 158(1): 1-15.

Bourdon, R. 1968. Les Bopyridae des mers Européennes. Mémoires du Muséum National D'Histoire Naturelle de Paris, Nouvel Série A, Zoologie, 50(2): 75-424.

Calado R.; Bartilotti, C. and Narciso, L. 2005. Short report on the effect of a parasitic isopod on the reproductive performance of a shrimp. Journal of Experimental Marine Biology and Ecology, 321: 13-18.

Calado, R.; Vitorino, A. and Dinis, M.T. 2006. Bopyrid isopods do not castrate the simultaneously hermaphroditic 
shrimp Lysmata amboinensis (Decapoda: Hippolytidae). Diseases of Aquatic Organisms, 73(1): 73-76.

Cash, C.E. and Bauer, R.T. 1993. Adaptations of the branchial ectoparasite Probopyrus pandalicola (Isopoda: Bopyridae) for survival and reproduction related to ecdysis of the host, Palaemonetes pugio (Caridea: Palaemonidae). Journal of Crustacean Biology, 13 (1): 111-124.

Conner, S.L. and Bauer, R.T. 2010. Infection of adult migratory river shrimps, Macrobrachium ohione, by the branchial bopyrid isopod Probopyrus pandalicola. Invertebrate Biology, 129(4): 344-352.

Ebert, D.; Carius, H.J.; Little, T. and Decaestecker, E. 2004. The evolution of virulence when parasites cause host castration and gigantism. The American Naturalist, 164(S5): S19-S32.

Hall, S.R.; Becker, C. and Cáceres, C.E. 2007. Parasitic castration: a perspective from a model of dynamic energy budgets. Integrative and Comparative Biology, 47(2): 295-309.

Hatcher, M.J.; Taneyhill, D.E. and Dunn, A.M. 1999. Population dynamics under parasitic sex ratio distortion. Theoretical Population Biology, 56(1): 11-28.

Hayashi, K. 1975. The Indo-West Pacific Processidae (Crustacea, Decapoda, Caridea). The Journal of the Shimoneseki University of Fisheries, 24(1): 47-145.

Jay, C.V. 1989. Prevalence, size and fecundity of the parasitic isopod Argeia pugettensis on its host shrimp Crangon francisorum. American Midland Naturalist, 121(1): 68-77.

Jordá, M.T. and Roccatagliata, D. 2002. Population dynamics of Leidya distorta (Isopoda: Bopyridae) infesting the fiddler crab Uca uruguayensis at the Río de la Plata estuary, Argentina. Journal of Crustacean Biology, 22(4): 719-727.

King, M. 1995. Fisheries Biology, Assessment and Management. Fishing News Books. Oxford, Blackwell Science Ltd., 352p.

Kuris, A.M. 1974. Trophic interactions: similarity of parasitic castrators to parasitoids. The Quarterly Review of Biology, 49(2): 129-148.

Manning, R.B. and Chace Jr., F.A. 1971. Shrimps of the family Processidae from the northwestern Atlantic Ocean (Crustacea: Decapoda: Caridea). Smithsonian Contributions to Zoology, 89: 1-41.

Markham, J.C. 1985. A review of the bopyrid isopods infesting shrimps in the northwestern Atlantic Ocean, with special reference to those collected during the Hourglass Cruises in the Gulf of Mexico. Memoirs of the Hourglass Cruises, 7(3): 1-156.

Markham, J.C. 1986. Evolution and zoogeography of the Isopoda Bopyridae, parasites of Crustacea Decapoda. p. 143-164. In: R.H. Gore and K.L. Heck (eds), Crustacean biogeography. Crustacean Issues, Vol. 4. Rotterdam, A.A. Balkema.

Masunari, S.; Castagini, A.S. and Oliveira, E. 2000. The population structure of Probopyrus floridensis (Isopoda, Bopyridae), a parasite of Macrobrachium potiuna (Decapoda, Palaemonidae) from the Perequê River, Paranaguá Basin, Southern Brazil. Crustaceana, 73(9): 1095-1108.
Miranda, I. and Mantelatto, F. 2010. Temporal dynamic of the relationship between the parasitic isopod Aporobopyrus curtatus (Crustacea: Isopoda: Bopyridae) and the anomuran crab Petrolisthes armatus (Crustacea: Decapoda: Porcellanidae) in southern Brazil. Latin American Journal of Aquatic Research, 38(2): 210-217.

Noël, P. 1976. L'évolution des caractères sexuals chez Processa edulis (Risso) (Décapode, Natantia). Vie et Milieu, 26: 65-104.

O'Brien, J. and Van Wyk, P. 1985. Effects of crustacean parasitic castrators (epicaridean isopods and rhizocephalan barnacles) on growth of crustacean hosts. p. 191-218. In: A.M. Wenner (ed) Factors in adult growth. Crustacean Issues, Vol. 3. Rotterdam, A.A. Balkema.

Oliveira, E. and Masunari, S. 1998. Population relationships between the parasite Aporobopyrus curtatus (Richardson, 1904) (Isopoda: Bopyridae) and one of its porcelain crab hosts Petrolisthes armatus (Gibbes, 1850) (Decapoda: Porcellanidae) from Farol Island, southern Brazil. Journal of Natural History, 32(10-11): 1707-1717.

Owens, L. 1983. Bopyrid parasite Epipenaeon ingens Nobili as a biological marker for the banana prawn, Penaeus merguiensis de Man. Australian Journal of Marine and Freshwater Research, 34(3): 477-481.

Pardo, L.M.; Fuentes, J.P.; Olguín, A. and Orensanz, J.M. 2009. Reproductive maturity in the edible Chilean crab Cancer edwarsii: methodological and management considerations. Journal of the Marine Biological Association of the United Kingdom, 89(8): 1627-1634.

Pike, R.B. 1960. The biology and post larval development of the bopyrid parasites Pseudione affinis G. O. Sars and Hemiarthus abdominalis (Kröyer) (= Phryxus abdominalis (Kroyer)). Journal of the Linnean Society of London, Zoology, 44(297): 239-251.

R Core Team. 2014. R: A Language and Environment for Statistical Computing. $\mathrm{R}$ Foundation for Statistical Computing, Vienna, Austria. Available at: http://www.R-project.org

Rasch, J.A. and Bauer, R.T. in press. Reproductive pattern and sexual system of the nocturnal seagrass shrimp Ambidexter symmetricus (Decapoda: Caridea: Processidae) in a Florida bay. Marine \& Freshwater Research.

Reinhard, E.G. 1949. Experiments on the determination and differentiation of sex in the bopyrid Stegophryxus hyptius Thompson. Biological Bulletin, 96(1): 17-31.

Richardson, H. 1904. Contributions to the Natural History of the Isopoda. Proceedings of the United States National Museum, 27(1350): 1-89.

Roccatagliata, D. and Lovrich, G.A. 1999. Infestation of the false king crab Paralomis granulosa (Decapoda: Lithodidae) by Pseudione tuberculata (Isopoda: Bopyridae) in the Beagle Channel, Argentina. Journal of Crustacean Biology, 19(4): 720-729. 
Romero-Rodríguez, J. and Román-Contreras, R. 2008. Aspects of the reproduction of Bopyrinella thorii (Richardson, 1904) (Isopoda, Bopyridae), a branchial parasite of Thor floridanus Kingsley, 1878 (Decapoda, Hippolytidae) in Bahía de la Ascensión, Mexican Caribbean. Crustaceana, 81(10): 1201-1210.

Romero-Rodríguez, J. and Román-Contreras, R. 2013. Prevalence and reproduction of Bopyrina abbreviata (Isopoda, Bopyridae) in Laguna de Términos, SW Gulf of Mexico. Journal of Crustacean Biology, 33(5): 641-650.
SAS Institute Inc. 2013. SAS Enterprise Guide 6.1 for SAS OnDemand, Cary, NC: SAS Institute Inc.

Sorensen, R.E. and Minchell, D.J. 1998. Parasite influences on host life history: Echinostoma revolutum parasitism of Lymnaea elodes snails. Oecologia, 115(12): $188-195$.

Turner, R.L. and Lawrence, J.M. 1979. Volume and composition of echinoderm eggs: implications for use of egg size in life-history models. p. 25-40. In: S.E. Stancky (ed), Reproductive Ecology of Marine Invertebrates. Columbia, University of South Carolina Press. 